\title{
A Novel Adenomatous Polyposis Coli Gene Mutation of Cribriform-Morular Variant Papillary Thyroid Carcinoma: A Case Report
}

\author{
Hee-Jung Kim, Nayeon Choi, and Man Ki Chung \\ Department of Otorhinolaryngology-Head and Neck Surgery, Samsung Medical Center, Sungkyunkwan University School of Medicine, \\ Seoul, Korea
}

\section{Cribriform-Morular 변이 갑상선 유두암 환자에서 새롭게 밝혀진 Adenomatous Polyposis Coli 유전자 돌연변이 증례}

김희정 · 최나연 · 정만기

성균관대학교 의과대학 삼성서울병원 이비인후과학교실

\author{
Received August 1,2017 \\ Revised August 24, 2017 \\ Accepted August 31, 2017 \\ Address for correspondence \\ Man Ki Chung, MD, PhD \\ Department of Otorhinolaryngology- \\ Head and Neck Surgery, \\ Samsung Medical Center, \\ Sungkyunkwan University \\ School of Medicine, \\ 81 Irwon-ro, Gangnam-gu, \\ Seoul 06351, Korea \\ Tel +82-2-3410-3579 \\ Fax $+82-2-3410-3879$ \\ E-mail manki.chung@gmail.com
}

Cribriform-morular variant papillary thyroid carcinoma (CMV-PTC) is a rare cancer that may arise in patients with familial adenomatous polyposis (FAP). Adenomatous polyposis coli (APC) gene mutation is associated with FAP, which is known as a premalignant lesion of colon cancer. In this report, we report a 16 years old patient of CMV-PTC comorbid with FAP, which was related with a new type of APC gene mutation.

Korean J Otorhinolaryngol-Head Neck Surg 2019;62(3):192-6

Key Words APC gene mutation .

Cribriform-morular variant of papillary thyroid carcinoma *

Familial adenomatous polyposis.

\section{서 론}

갑상선 유두암(papillary thyroid carcinoma, PTC)의 한 아 형 중 cribriform-morular variant(CMV)는 매우 드문 조직학 적 아형으로, 조직검사상 사상체 및 방추체 모양의 세포들이 관찰된다. ${ }^{1,2)} \mathrm{CMV}-\mathrm{PTC}$ 의 임상 양상은 아직 뚜렷하게 보고되 는 것은 없으나, $50 \%$ 이상에서 가족성 선종성 용종증(familial adenomatous polyposis, FAP)이 동반된다. ${ }^{3)}$

FAP는 대장암의 전암성 병변으로 adenomatous polyposis

This is an Open Access article distributed under the terms of the Creative Commons Attribution Non-Commercial License (http://creativecommons.org/licenses/by-nc/4.0) which permits unrestricted non-commercial use, distribution, and reproduction in any medium, provided the original work is properly cited.
coli(APC) 유전자의 5q21 변이와 연관되어 있으며, APC 유 전자 변형은 어린 나이에서 대장암 발병 위험성을 높이므로, CMV-PTC 환자들은 대장 내시경검사를 통한 대장 및 소장 의 용종 여부 및 $\mathrm{APC}$ 유전자의 변이 여부 검사가 필요하다. ${ }^{4)}$ 갑상선암이 $\mathrm{FAP}$ 를 가진 환자의 첫 증상으로 발현될 수 있으 며, 4 12세 어린 환자들의 약 30\%에서는 대장용종의 발현 이 있기 전에 갑상선암이 먼저 발견되기도 한다. ${ }^{5)}$

저자들은 갑상선의 다발성 결절을 주소로 내원한 16 세 환 자의 CMV-PTC와 APC 유전자 돌연변이를 보이는 FAP가 동반된 증례에서, 이전에 보고되지 않은 APC 유전자 돌연변 이가 관찰되어 보고하고자 한다. 

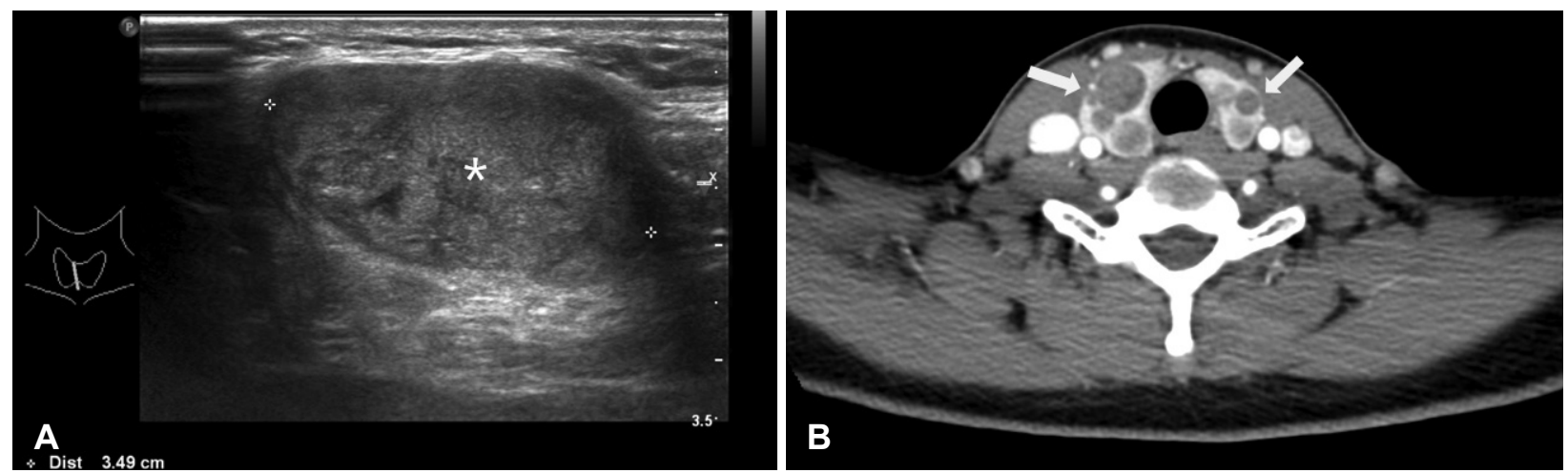

Fig. 1. Representative images of US and CT. Initial US scan shows huge thyroid mass with isoechoic to hypoechoic heterogeneous attenuation about $3.5 \mathrm{~cm}$ sized- nodule in isthmus of thyroid (white asterisk) (A). Preoperative CT scan shows multiple indeterminate solitary nodules in both thyroid glands (white arrows). There is no evidence of enlarged lymph node which is suspicious for malignancy (B). US: ultrasonograpy, CT: computed tomography.

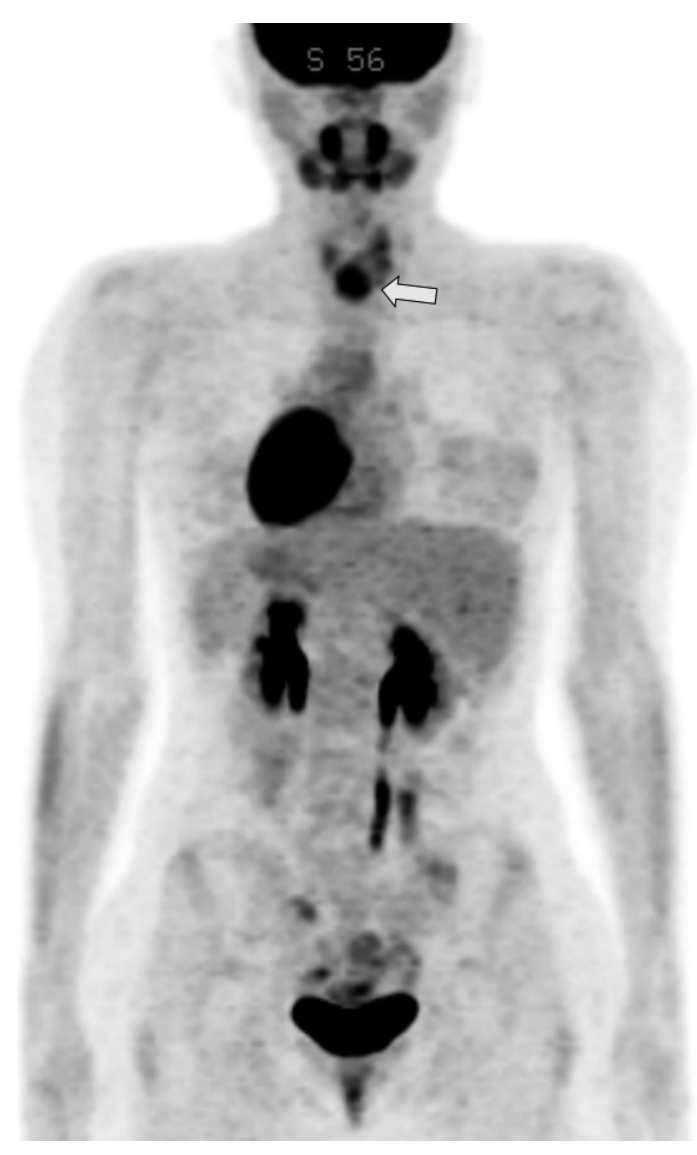

Fig. 2. Preoperative PET-CT scan shows hypermetabolic mass in thyroid isthmus and multiple nodules with increased fluodeoxy glucose uptake in both thyroid lobes (arrow).

\section{증 례}

16세 여자 환자는 2016년 5월에 전경부에 만져지는 종물로 내원하여, 시행한 갑상선 초음파 및 컴퓨터 전산화단층촬영 상 갑상선 협부의 $3.5 \mathrm{~cm}$ 크기의 종양과 양측 갑상선에 다양 한 크기의 결절이 여러 개 관찰되었다(Fig. 1). 양전자 방출 컴 퓨터단층촬영(positron emission tomography-computed tomography)에서는 갑상선에 다발성 섭취 증가가 보였고, 경부 림프절이나 전신 전이는 관찰되지 않았다(Fig. 2).

흡입천자세포검사 결과상 사상체 및 상실배 모양의 조직이 관찰되었고, 면역염색상 $\beta$-catenin 양성 소견의 갑상선암으로 진단되어, 이에 전신마취하 갑상선 전 절제술을 시행하였다. 육안적으로 갑상선 피막 외 침범은 보이지 않았다.

최종 병리조직검사 결과상, 갑상선 협부에 최대 $3.5 \times 3 \times$ $2.5 \mathrm{~cm}$ 의 종양과 함께 총 18 개 이상의 다양한 크기의 종양이 갑상선 유두암으로 진단되었고, 현미경적으로 갑상선 피막 외 침범과 혈관 침범 소견은 관찰되지 않았다. 최종 조직검사 결 과는 이전 세침흡인검사 결과와 마찬가지로 상실배 모양(morular morphology) 및 사상체 모양(cribriform morphology)의 조직과 함께 $\beta$-catenin 면역염색 양성으로 CMV-PTC에 합 당한 소견이 보고되었다(Fig. 3). 수술 2개월 이후 방사선 요 오드 치료를 $50 \mathrm{mCi}$ 를 추가로 1차례 시행하였다.

CMV-PTC는 가족성 선종성 용종증이 동반되는 경우가 많 기 때문에, 병력 청취 및 유전자 분석을 시행하였다. 환자의 아버지가 대장의 용종증이 있었고, 대장암으로 10년 전 사망 한 가족력이 있었다. 이에 위 및 대장 내시경검사와 APC 유 전자 분석을 시행하였다. 위 내시경검사상, 위저 용종(stomach fundic polyp) 및 대장 내시경검사상 소장에서 1개, 대장에 서 15 개의 선종이 관찰되었다. APC 유전자에 대한 염기서열 분석 결과, 5 번 염색체 q arm의 21번 유전자 4181 4188번째 염 기서열이 결손(deletion)되어 1394번째 아미노산인 아스파트 산(Aspartic acid)이 글리신(Glycine)으로 치환되면서, 조기 종결(premature termination)되는 프레임시프트 돌연변이 (frameshift mutation)가 관찰되었다(Table 1, Fig. 4). 이 돌연 변이는 이전에 보고된 적 없는 새로운 서열 변화이다.)

환아는 다발성 갑상선암 및 가족성 선종성 용종증과 더불 
어 시력 저하를 호소하여 시행한 안과 검진상 좌안 망막 하 방으로 색소가 침착된 선천성 망막 색소 침착성 상피 비대증 (congenital hypertrophy of the retinal pigment epithelium, $\mathrm{CHRPE)}$ 소견이 관찰되었고, 그 외 다른 피부 병변은 관찰되 지 않았다(Fig. 5).

수술 후 1 년째, 환자는 초음파검사 및 동위원소검사 등을 통해 정기검진을 시행하고 있으며, 재발은 관찰되지 않았다. 대장 선종에 대해서는 고등학교 졸업 이후에 수술적 치료를 고려하고 수술 전까지 1년마다 대장 내시경 및 위 식도 내시경 을 시행하고, 좌측 눈 병변에 대해서도 1 년마다 정기검진을 시 행할 예정이다.

\section{고 찰}

CMV-PTC는 갑상선 유두암의 아형으로 분류되지만, 전
형적인 유두암과 구별되는 특징적인 임상 양상을 가지고 있 다. 갑상선 유두암은 최근 World Health Organization 분류법 에 의하여 15 가지로 분류되며, 이 중 CMV-PTC는 $0.2 \%$ 를 차 지하는 드문 아형이다. ${ }^{7)}$

갑상선 유두암이 40대에 호발하는 반면 CMV-PTC는 20대 에 호발하며, ${ }^{3)}$ 본 증례와 같이 10 대에도 비교적 호발하는 것 으로 알려져 있다. 또한 갑상선 유두암은 림프절 전이의 유병 률이 높은 반면에, $\mathrm{CMV}-\mathrm{PTC}$ 는 약 $10 \%$ 정도의 림프절 전이 를 보이며 원격 전이의 유병률도 낮게 관찰되었다.,8

$\mathrm{CMV}-\mathrm{PTC}$ 가 임상적으로 가장 특징적인 것은 $\mathrm{FAP}$ 와의 연관성이다. FAP는 상염색체 우성 질환으로, 대장의 다발성 용종과 APC 유전자의 5 번 염색체 q arm의 22번 유전자에서 변이가 관찰된다. FAP 환자는 거의 대부분이 대장암으로 진 행하며, 어린 나이에 다발성으로 발생할 수 있다. 기존의 메타 분석에서는 $53 \%$ 의 CMV-PTC 환자에서 FAP가 동반되었으
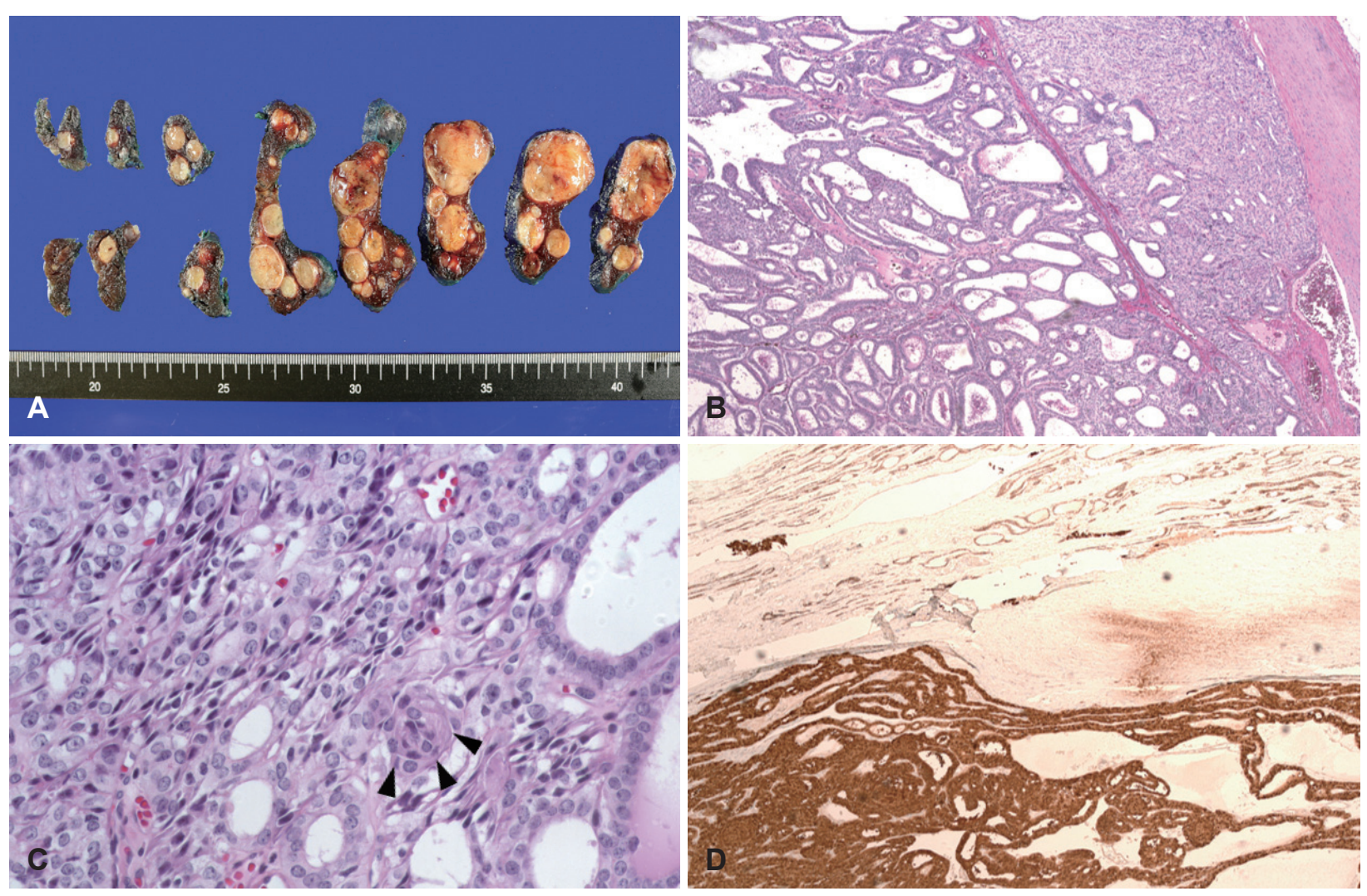

Fig. 3. Thyroid gland cross section shows total 18 mass. Largest diameter of thyroid tumor was measured $3.5 \times 3 \times 2.5 \mathrm{~cm}$ at isthmus (A). Thyroid tumor with compact arrangement of cribriform, follicular, papillary, trabecular, and solid patterns by columnar cells thick. The tumor is surrounded by a fibrous capsule and colloid is not present (H\&E, $\times 50)(B)$. Morular (cuboid) shaped cells shows (arrowheads) $(H \& E \times 400)(C)$. The nuclei and cytoplasm was stained by $\beta$-catenin $(\times 50)(D)$.

Table 1. APC gene sequencing analysis report (genomic DNA isolated from peripheral blood leukocytes)

\begin{tabular}{ccccccc}
\hline Gene & Isoform & NT change & AA change & Zygosity & IHR & Type \\
\hline APC & NM_000038.5 & c.4181_4188del & P.Asp1394Glyfs*12 & Het & AD & PV \\
\hline
\end{tabular}

APC: adenomatous polyposis coli, DNA: deoxyribonucleic acid, AA: amino acid, AD: autosomal dominant, Het: heterozygous, IHR: inheritance pattern, NT: nucleotide, PV: pathogenic variant 


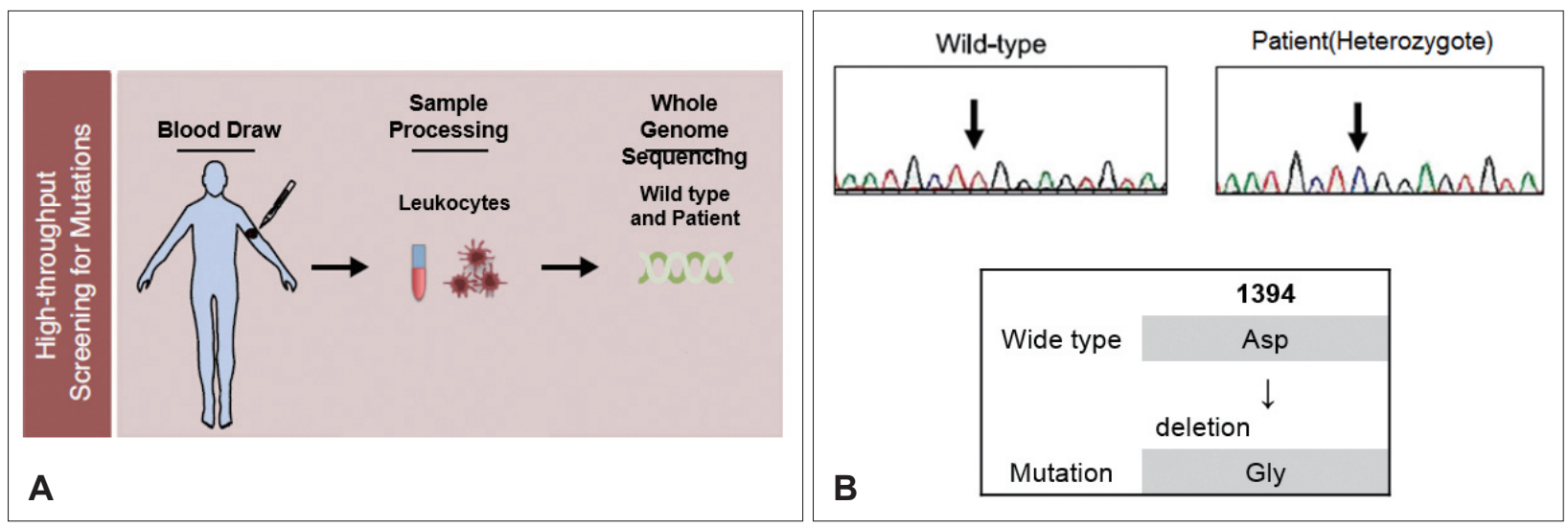

Fig. 4. APC gene analysis diagram (A). Through direct sequencing, APC gene on chromosome 5q21-22 of the cribriform-morular variant papillary thyroid carcinoma patient was analyzed. A novel gene mutation, which deleted $4181-4188$ nucleotides substitute Glycine for Aspartic acid, was discovered causing premature termination of the APC protein (B). APC: adenomatous polyposis coli, ASP: aspartic acid, Gly: glycine.
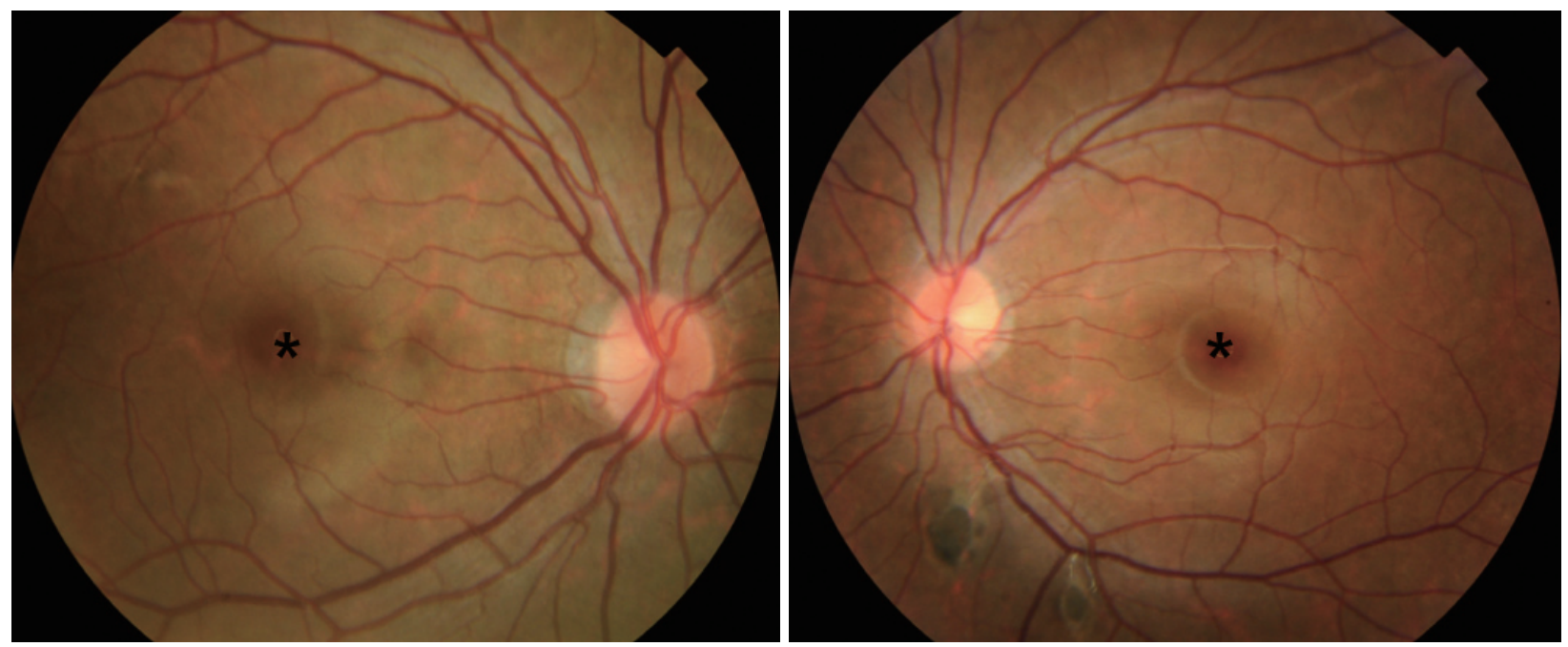

Fig. 5. Fudus photography. Left fundus shows hyper pigmented lesion with surrounding hypo-pigmentation (asterisks).

며, 이 중 약 $50 \%$ 에서 갑상선암이 먼저 진단되었다. ${ }^{3,9)}$ 본 환 자의 경우 $\mathrm{APC}$ gene mutation 확인을 위하여, 말초혈액의 백혈구로부터 Genomic DNA를 추출하여 5번 염색체의 $\mathrm{q}$ $\operatorname{arm}$ 의 21 22번째에 위치한 APC 유전자의 모든 coding exon 및 인접 intron 부위의 염기서열을 direct sequencing 을 통한 염기서열 분석법으로 확인하였다. 총 15 개 exon의 염색체 분석에서 APC 유전자의 5번 염색체 q arm의 21번 유전자 4181 4188번째 염기서열이 deletion 되면서 Aspartic acid가 Glycine으로 치환되는 변이가 관찰되면서, $\mathrm{APC}$ 유전 자가 조기에 종결되었다. 대부분 밝혀진 APC gene mutation 의 경우, 3927 3931 염기서열이 deletion 되면서 frameshift mutation이 발생하여 APC 유전자의 premature termination 에 의해 변이가 된다고 밝혀져 있으나, 본 증례에서는 기존과 는 달리 4181 4188번 염기서열의 deletion에 의한 APC 유전 자 돌연변이로, 기존에 보고되지 않은 유전자 변이이다.
이와 더불어 $\mathrm{FAP}$ 를 가진 환자의 경우 약 $75 \%$ 에서 $\mathrm{CHRPE}$ 가 동반되고 있으며, 특히 양측 망막의 색소 침착 혹은 병변 의 저색소증이 동반된 경우에는 $\mathrm{FAP}$ 와 연관된 $\mathrm{CHRPE}$ 의 지 표라고 할 수 있어 CMV-PTC 환자의 경우, 정기적으로 망막 검사가 필요하다. ${ }^{10)}$

CMV-PTC는 조직학적으로 cribriform의 구조를 가지고 있고, morule 형태의 세포 구조를 가지고 있으며,2) $\beta$-catenin 면역염색에서 핵과 세포질이 염색되는 것을 확인함으로써 진 단을 할 수 있다. ${ }^{11}$

CMV-PTC의 치료법은 유병률이 낮아 정립되지는 않았지 만, 여타 갑상선 유두암의 치료 원칙을 따른다. 본 증례와 같 이 다발성 갑상선암이 흔하기 때문에 갑상선 전 절제술을 시 행하며, 림프절 전이가 확인이 되면 림프절 절제술을 추가하 게 된다. ${ }^{3,912)}$ 본 증례에서는 갑상선의 다발성 종양에 대해 전 갑상선 절제술을 시행하였고, 대장 용종에 대해서는 경과관찰 
후 FAP의 치료 원칙에 따라 환아 성장 이후 대장의 부분 절제 술을 고려하고 있다.

본 증례에서는 드물게 보고되고 있는 $\mathrm{CMV}-\mathrm{PTC}$ 환자에 서 전형적인 임상 양상을 가졌으나, 이전에 보고되지 않았던 새로운 $\mathrm{APC}$ 유전자의 변형이 관찰되었고, FAP가 동반된 증 례를 진단 및 치료하였기에 보고하였다. $\mathrm{CMV}-\mathrm{PTC}$ 는 갑상선 암의 특징적인 임상 양상과 더불어, 대장암의 전암성 병변으 로 알려진 FAP가 흔하게 동반되기 때문에 이에 대한 각별한 주의가 필요하겠다.

\section{REFERENCES}

1) Xu B, Yoshimoto K, Miyauchi A, Kuma S, Mizusawa N, Hirokawa $\mathrm{M}$, et al. Cribriform-morular variant of papillary thyroid carcinoma: a pathological and molecular genetic study with evidence of frequent somatic mutations in exon 3 of the beta-catenin gene. J Pathol 2003; 199(1):58-67.

2) Hirokawa M, Maekawa M, Kuma S, Miyauchi A. Cribriformmorular variant of papillary thyroid carcinoma--cytological and immunocytochemical findings of 18 cases. Diagn Cytopathol 2010; 38(12):890-6

3) Lam AK, Saremi N. Cribriform-morular variant of papillary thyroid carcinoma: a distinctive type of thyroid cancer. Endocr Relat Cancer 2017;24(4):R109-21.

4) Tomoda C, Miyauchi A, Uruno T, Takamura Y, Ito Y, Miya A, et al.
Cribriform-morular variant of papillary thyroid carcinoma: clue to early detection of familial adenomatous polyposis-associated colon cancer. World J Surg 2004;28(9):886-9.

5) Plail RO, Bussey HJ, Glazer G, Thomson JP. Adenomatous polyposis: an association with carcinoma of the thyroid. Br J Surg 1987;74(5): $377-80$.

6) Jasperson KW, Patel SG, Ahnen DJ. APC-Associated Polyposis Conditions. University of Washington 1998 Dec 18 [updated 2017 Feb 2].

7) Lam AK. Pathology of endocrine tumors update: world health organization new classification 2017-other thyroid tumors. AJSP: Reviews and Reports 2017;22(4):209-16.

8) Pradhan D, Sharma A, Mohanty SK. Cribriform-morular variant of papillary thyroid carcinoma. Pathol Res Pract 2015;211(10):712-6.

9) Jung CK, Choi YJ, Lee KY, Bae JS, Kim HJ, Yoon SK, et al. The cytological, clinical, and pathological features of the cribriform-morular variant of papillary thyroid carcinoma and mutation analysis of CTNNB1 and BRAF genes. Thyroid 2009;19(8):905-13.

10) Chen CS, Phillips KD, Grist S, Bennet G, Craig JE, Muecke JS, et al. Congenital hypertrophy of the retinal pigment epithelium (CHRPE) in familial colorectal cancer. Fam Cancer 2006;5(4):397-404.

11) Melo M, da Rocha AG, Vinagre J, Batista R, Peixoto J, Tavares C, et al. TERT promoter mutations are a major indicator of poor outcome in differentiated thyroid carcinomas. J Clin Endocrinol Metab 2014; 99(5):E754-65.

12) Kuma S, Hirokawa M, Xu B, Miyauchi A, Kukudo K, Sano T. Cribriform-morular variant of papillary thyroid carcinoma. Report of case showing morules with peculiar nuclear clearing. Acta Cytol 2004;48(3):431-6 